\title{
Temperature Regime and Its Effect on Energy Potentials of Bio-Oil From Ficus Exasperata Wood Residue
}

\author{
Gloria Titi Anguruwa* \\ Department of Forest Products Development and Utilization \\ Forestry Research Institute of Nigeria. P. M. B 5054, Ibadan. Oyo State, Nigeria \\ Abiodun Oluwafemi Oluwadare \\ Professor of Pulp \& Paper, Department of Forest Production and Products \\ University of Ibadan. Oyo State, Nigeria
}

\begin{abstract}
This study was to determine the ultimate and proximate analysis of bio-oil produced from sawdust of Ficus exasperata. A vacuum reactor was used to extract bio-oil from sawdust at three temperature regime; 500, 550 and $600^{\circ} \mathrm{C}$ for use in energy generation and other value added products. Physical properties, Ultimate analysis $(\mathrm{C}, \mathrm{H}, \mathrm{N}, \mathrm{O})$, heating value, GC-MS of bio-oil were determined using standard procedure. Result shows that bio-oil at $500^{\circ} \mathrm{C}$ had highest yield $(42.4 \%)$ with lowest bio-char $(21.7 \%)$, density $\left(1.12 \mathrm{Kg} / \mathrm{dm}^{3}\right), \mathrm{pH}(3.43)$, Moisture content (25.85\%) and Kinematic viscosity (299.92cSt). Average content of CHNO was 77.42, 4.77, 0.10 and $17.81 \%$ respectively. Proximate analysis at $500^{\circ} \mathrm{C}$ shows highest $\% \mathrm{Ash}$ and lowest $\mathrm{HV}$ as $0.09 \%$, and $34.08 \mathrm{Mjkg}^{-1}$ respectively, while lowest $\% \mathrm{Ash}$ and highest $\mathrm{HV}$ of $0.05 \%$ and $34.10 \mathrm{Mjkg}^{-1}$ respectively were obtained at $600^{\circ} \mathrm{C}$. GC-MS peaks showed that the bio-oil was composed of hydrocarbons and oxygenated compounds while oxylic, carboxylic and benzoic acids were detected.
\end{abstract}

Keywords: Wood residue; pyrolysis, physical properties, heating value, GC-MS.

DOI: $10.7176 /$ JETP/9-8-01

Publication date: November $30^{\text {th }} 2019$

\section{INTRODUCTION}

Solid waste management present a major challenge in developing county like Nigeria where rapid population growth, social and cultural change and limited financial resources all contributes to environmental degradation and waste disposal challenges. The wood residues (sawdust) from most of the Sawmills are being burnt and dumped on water ways thereby causing environmental problem/pollution.

General observation and research shows that wood waste have potential in production of fuels (energy) and chemicals. They are said to be in abundance and doesn't alter or contend with food supply Sukumaran et al. (2010). In order to minimize over reliance on fossil fuels there is need for energy conservation and utilization of renewable energy resources. However, a more conducive method is the reduction in the $\mathrm{CO}_{2}$ present in the atmosphere by generating energy from bio-oil, which is a product of biomass pyrolysis Brown et al. (2011). Biomass utilization is one of the most cost-effective routes to carbon-neutral energy and is expected to be the source of huge practical value to produce renewable liquid fuels He et al. (2009).

Biomass is an attractive energetic source, since it is renewable, available in most countries and can replace fossil fuels. For its efficient application to energy conversion processes, the knowledge on its physical-chemical properties is very important and determines the behaviour of the fuels in processes such as combustion, gasification and pyrolysis (Kazagic and Smajevic, 2007). In addition, identification and classification potential biomass based on its potential value, will allow higher quality of its integration and optimized result (Lim et al., 2013). There are several routes of biomass conversion: generation of heat energy, transport fuel and chemical feedstock. Sawdust can be utilized and channel for energy generation through pyrolysis. The bio-oil collected can be used as ingredient in the manufacturing of many chemical and also as liquid fuels

This study is aimed at production and characterization of bio-oil for energy production and other value-added products

\section{MATERIALS AND METHOD}

\subsection{Sample Preparation and Bio-oil Extraction}

Wood residue (sawdust) of Ficus exasperata was collected and sieved (5-9mesh). Samples of 1200 grams were oven-dried at $103 \pm 2^{\circ} \mathrm{C}$ for 24 hours to $12 \%$ moisture content. A fabricated vacuum pyrolysis Chamber was used to convert sawdust to bio-oil. Three replicates of the oil were obtained at different temperature regime $500^{\circ} \mathrm{C}$, $550^{\circ} \mathrm{C}$ and $600^{\circ} \mathrm{C}$. The evolving gas was distilled in the condenser to form bio-oil which was collected inside a conical flask. 


\subsection{Determination of Bio-oil yield and Char}

2.2.1 Bio-oil yield was calculated as the percentage of the sawdust fraction of the feed that was condensed as biooil, using Equation:

$$
\text { Bio }- \text { oil yield }=\frac{\text { Weightof bio }- \text { oil }}{\text { Weightof sawdust }} \times 100
$$

2.2.2 Char yield was calculated as the percentage of the sawdust fraction, which is converted to a solid carbonized (char), using Equation.

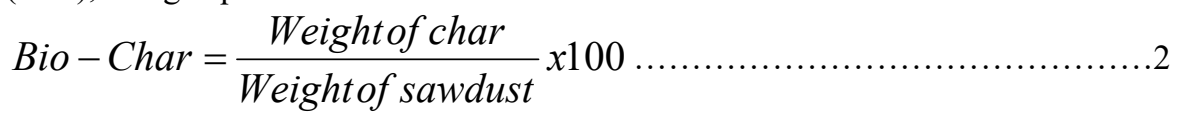

\subsection{Physical Properties of Bio-Oil}

\subsection{1 $\mathrm{pH}$ determination:}

This was carried out using a $\mathrm{pH}$ meter from Eutech Instruments, a type of $\mathrm{pH}$ tutor which has an electrode that was calibrated with two buffer solutions. The electrode was directly dipped into the bio-oil sample expressed as a $\mathrm{pH}$ of bio-oil.

2.3.2 Density:

The density of a material is defined as mass per unit volume of sample and this was determined according to (ASTM D 4052) using digital density meter. One $1 \mathrm{~mL}$ of bio-oil was injected into density meter at $25^{\circ} \mathrm{C}$ and repeated three times. The average of the recorded values was expressed as density in $\mathrm{g} / \mathrm{cm}^{3}$.

2.3.3 Kinematic Viscosity:

Is a measure of the resistance to gravity flow of a fluid. Viscosity of a liquid is an important property since it affects the flow of the liquid through pipelines. The viscosity was measured with a Cannon-Fenske up-flow viscometer. A sample $(20 \mathrm{ml})$ of each of the bio-oils was placed in the viscometer and the flow was observed at $40^{\circ} \mathrm{C}$. The unit of measurement is centistokes $(\mathrm{cSt})$.

2.3.4 Flash point:

Is a measure of the volatility of the oil, as well as its ease of ignition. The higher the number, the safer the handling of the oil and lowers the risk of accidental vapor ignition. The flash point was determined by heating a sample of the fuel in a stirred container and passing a flame over the surface of the liquid (ASTM D-93).

2.3.5 Cloud point

This was carried out using a cryostat. The cryostat was switched on and the automatic temperature was also turned on. The temperature of the surrounding outside the cryostat was recorded. Another thermometer was inserted into the fluid bath in order to take the temperature of the content of the fluid bath (methanol). As the temperature of the surrounding (bath fluid) dropped, with the test jar in the cooling bath, the oil sample in the test jar was checked intermittently for the temperature at which a significant amount of cloud was present in test jar (Cloud point). The test jar was removed and the temperature recorded.

2.3.6 Pour point:

After recording the value of the cloud point, the thermometer was removed from the test jar and capped with a wooden cork. The test jar was carefully placed into a metal air and the well was covered to prevent heat loss. The oil sample was allowed to freeze completely and was taken out of $d$ metal well. The wooden cork was removed and at about $90^{\circ} \mathrm{C}$ the test jar was tilted horizontally for $5 \mathrm{sec}$ to check for surface movement. Close observation was made to see at what point the frozen bio oil would pour. The temperature at which the bio oil poured was taken.

\subsection{Ultimate Analysis}

This was carried out using ASTM 3174-76. $2 \mathrm{~g}$ of oil sample was weighed into platinum crucible and placed in a leibig-pregle chamber containing magnesium percolate and sodium hydroxide. The sample was burnt off to produce carbon dioxide and water. The $\mathrm{CO}_{2}$ was absorbed by Sodium hydroxide while water was absorbed by magnesium percolate. The result of Carbon, Hydrogen and Nitrogen where obtained while oxygen was calculated by difference using formular

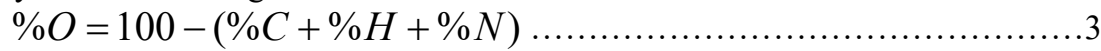

\subsection{Proximate Analysis of Bio-oil}

2.5.1 Percentage volatile matter determination: The amount of volatile present is equal to loss in weight which is calculated using the formula

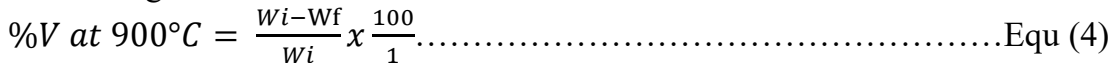

$$
\begin{aligned}
& \text { Where }=W_{i}=\text { Initial mass of the sample, }
\end{aligned}
$$


$W_{f}=$ Final constant mass of the sample.

2.5.2 Percentage ash content determination: The amount of residual white grey matter is determined by difference.

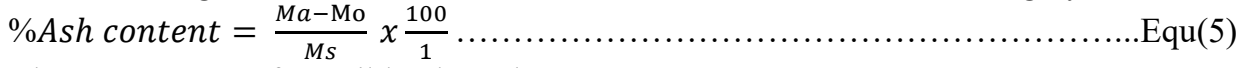

Where $M_{a}=$ Mass of Crucible plus ash,

$$
\begin{aligned}
& M_{o}=\text { Mass of empty crucible, } \\
& M_{S}=\text { Mass of sample }
\end{aligned}
$$

2.5.3 Percentage fixed carbon determination: The amount of fixed carbon is calculated using the formula

$100-(\%$ moisture $+\%$ Ash $+\%$ Volatile matter $)$ Equ (6)

2.5.4 Heating value (calorific value): The calorific value of bio oil was determined in according to ASTM D-4809 by burning a weighed sample in an oxygen-bomb calorimeter, Leco AC-350 under controlled conditions.

\subsection{Gas Chromatography-Mass Spectrometry Analysis}

The oil obtained was methylated and analysed using Gas Chromatography-Mass Spectroscopy. The GC-MS analysis was done using the instrument Trace GC Ultra Thermo Scientific DSQ II, equipped with a VF-5ms fused silica capacity column of $30 \mathrm{~m}$ length, $0.25 \mathrm{~mm}$ diameter and $0.25 \mathrm{um}$ film thickness. For GC-MS detection, an electron ionization system with ionization energy of 70Ev was used. Helium gas $99.99 \%$ of purity was used as a carrier gas as well as an eluent. The flow rate of Helium gas was set to $1.5 \mathrm{~mL} / \mathrm{min}$. the sample injector temperature was maintained at $200^{\circ} \mathrm{C}$. Initially oven temperature was maintained at $140^{\circ} \mathrm{C}$ for 1 minute, and the temperature was gradually increased up to $300^{\circ} \mathrm{C}$ for 5 minutes. $1 \mathrm{ul}$ of sample was auto injected for analysis.

In identifying the various components, the relative percentage amount of each component was calculated by comparing its average peak area to the total areas. The detection employed by using the NIST (National Institute of Standards and Technology) library ver.2.0 (2005) (Lafferly 1980; and Stein's 1990). Interpretation of GC-MS was conducted using the database of NIST library having more than 62,000 patterns. The spectrum of the component was compared with that of a known spectrum, the components were saved in the NIST library ver. 2.0. The name, molecular weight and molecular formula of components of the test materials were ascertained.

\section{RESULTS AND DISCUSSION}

\subsection{Bio-Oil Yield}

The yield of bio-oil decreased with increased in pyrolysis temperature. The average values of $42.4,41.0$ and $40.3 \%$ were recorded at pyrolysis temperature of $500^{\circ} \mathrm{C}$ at $550^{\circ} \mathrm{C}$ and $600^{\circ} \mathrm{C}$ respectively, while the quantity of bio-char slightly increased with increase in temperature with average values of $21.71,21.84$ and $21.97 \%$ at pyrolysis temperature of $500^{\circ} \mathrm{C}, 550^{\circ} \mathrm{C}$ and $600^{\circ} \mathrm{C}$ respectively (Fig 1 ).

Pyrolysis of $F$. exasperata residue at $500^{\circ} \mathrm{C}$ gave highest bio-oil yield of $42.4 \%$ with lower bio-char, this result is in agreement with the range of $40-48 \%$ oil yield recorded in pine wood by Nanda et al. (2014). The result also compare favourably with the values obtained by Thangalazhy et al. (2010); Ingram et al. (2008). It was observed that high temperature produces more gas than oil, it is therefore said that bio-oil yield decrease with increase in temperature.

\subsection{Physical Properties of Bio-oil}

The result presented in Table 1 shows the mean values of the physical properties of bio-oil produced from $F$. exasperata wood residues. $\mathrm{pH}$ and density of the oil increased with decrease in temperature while moisture content increases with increase in temperature. The average value of $3.43,1.12 \mathrm{~kg} / \mathrm{cm}^{3}$ and $25.85 \%$ were obtained for biooil $\mathrm{pH}$, density and moisture content respectively. A trend of increase was also observed in pour point, cloud point and flash point of the bio-oil with increase in pyrolysis temperature having average values of 87.69, 8.33 and $4.50^{\circ} \mathrm{C}$ respectively. On the other hand, increase in temperature reduces viscosity of the bio-oil with average values of $299.92 \mathrm{cSt}$. The $\mathrm{pH}$ value of the bio-oil is in line with the result recorded by Bridgwater et al. 1999 that is, biooil generally contains considerable amount of organic acids such as formic and acetic acid which provides the biooil its low pH of about 2-3. Bio-oil generally behaves just like acidic and they comprise also diverse amounts of organic acids (Czernik and Bridgwater, 2004; Oasmaa and Czernik, 1999).

As a vital property (physical) that can be used in the characterization of bio-oil products, the density of pyrolysis oil is in agreement with the range of $1.2-1.3 \mathrm{~kg} / \mathrm{dm}^{3}$ recorded by Oasmaa and Peacocke (2001), and it is influenced by water content of bio-oil. Density is said to be high when the temperature increase and by some polar solvents addition such as acetone or methanol (Czernik and Bridgwater, 2004).

Generally, when the water content in bio-oil is high, there is usually decrease in density (Oasmaa et al., 1997). However, moisture content of bio-oil in this study is higher than 18-19\% reported by Mohamad et al. (2009) though it all depends on the production conditions. Also, the quantity of moisture in a product depends largely on the process parameters (Mohamad et al., 2009). The low viscosity is a sign of low pour point (Oasmaa and Peacock, 2001). Oasmaa et al. (1997) stated that flash point values of pyrolysis liquids change from $40-100^{\circ} \mathrm{C}$. 


\subsection{Ultimate Analysis}

Average Carbon, Hydrogen, Nitrogen and Oxygen content in the oil was 77.42, 4.77, 0.10 and $17.81 \%$ respectively. However, variation in temperature of bio-oil showed that $\mathrm{N}$ content decreased from $0.13 \%$ at $500{ }^{\circ} \mathrm{C}$ to $0.08 \%$ at $600^{\circ} \mathrm{C}$. The percentage of $\mathrm{H}$ content in the oil was higher $5.13 \%$ at $500^{\circ} \mathrm{C}$ and lower value of $4.41 \%$ was obtained at $600^{\circ} \mathrm{C}$. The content of $\mathrm{C}$ decreased with increase in temperature from $78.45 \%$ at $600^{\circ} \mathrm{C}$ to $76.39 \%$ at $500^{\circ} \mathrm{C}$. Oxygen content of $18.48 \%$ was higher at $500^{\circ} \mathrm{C}$ compared to $17.1 \% 3$ obtained at $600^{\circ} \mathrm{C}$ (Table 1).

The average values of $\mathrm{H}, \mathrm{N}$ and $\mathrm{O}$ obtained in this study was lower compared to the result obtained in bio-oil of pine wood H-5.31, N-1.12 and O-53.13 Fei et al. (2007) while C content in the Pyrolysis oil of $F$. exasperata is higher than $45.95 \%$ obtained in bio oil of pine sawdust, Braz and Cmkovic (2014).

The result shows that the bio-oil contains trace of Nitrogen $0.10 \%$ which is an indication that the oil is environment friendly. On the other hand, the amount of Oxygen content in the bio-oil is as a result of the water content present in it (Bardalai and Mahanta, 2015). Though high oxygen content in oil has some negative effects such as, reduction in heating value of the liquid and it is also responsible for corrosive nature and instability of the bio-oil. Oxygen content in this study is less than $20 \%$, not different from oxygen content in fossil fuel, therefore, the oil is said to be considerable because of the low oxygen content Kiky et al. (2015); Czernik and Bridgwater (2004). It could be inferred that temperature influenced the chemical characteristics of the bio-oil Nanda et al. (2014)

\subsection{Proximate Analysis}

It was observed that bio oil produced at $500^{\circ} \mathrm{C}$ gave the highest $\%$ ash content of $0.09 \%$, but lowest $\%$ ash content of $0.05 \%$ was recorded at $600^{\circ} \mathrm{C}$. However, heating value increased with increase in temperature. The highest heating value of $34.10 \mathrm{Mjkg}^{-1}$ was obtained at $600^{\circ} \mathrm{C}$ while lowest value of $34.08 \mathrm{Mjkg}^{-1}$ was recorded at $500^{\circ} \mathrm{C}$ (Table 1).

The heating value or the calorific value of any oil indicates the energy content present in it, which is a very important factor for choice of the oil for a specific application (Bardalai and Mahanta, 2015). The heating value obtained in this study is higher than the result obtained for oil from pine sawdust by (Braz and Cmkovic, 2014). Also Fei et al (2007) recorded a lower heating value in oil produced from corn stover. According to literature, the calorific value in most bio-oils are found within 15-36 MJ/kg Biswal et al. (2013), Mullen et al. (2010), Bertero et al. (2014) and Demiral et al. (2013) which is always lower than that of conventional petroleum fuels (40-50 $\mathrm{MJ} / \mathrm{kg}$ ). This study shows higher heating value wss obtained at higher temperature. It could be inferred that the lower the ash content of a fuel material, the higher the fixed carbon and by extension the heating value Oluwadare et al. (2016).

\subsection{GC-MS of bio-oil.}

Table 2 shows the results of chromatogram for bio-oil produced from the wood residue of $F$. exasperata. The results were matched with NIST library to identify the compounds present; the Identification of the compounds was based on the peak area, molecular weight and molecular formula. GC-MS chromatogram in Fig 2 detected 21 peaks for $500^{\circ} \mathrm{C}$ and prominent peaks were observed at the retention time ranging between $0.00-26.5 \mathrm{~min}$. The peak at 4.21 retention times has the highest percentage $13.46 \%$ peak area; this was identified as 2, 4dimethylheptane, with molecular formula $\mathrm{C}_{9} \mathrm{H}_{20}$ and molecular weight of 128 while the lowest peak was obtained at 18.20 retention time with percentage peak area of $2.11 \%$, identified as 6-methyloctadecane $\mathrm{C}_{19} \mathrm{H}_{40}$ with molecular weight 268. The GC-MS analysis went further to show that there was no significantly different in the bio-oil produced at the varied temperature regime except for the presence of Phthalic acid, Benzoic acid, and Oxalic acid at $500^{\circ} \mathrm{C}$ (Table 2).

General observation made in Fig. 5 by comparing the compounds present in each bio-oil sample shows that bio-oil produced at $500^{\circ} \mathrm{C}$ is composed mostly of hydrocarbons; approximately $71.95 \%$ aliphatic $\left(\mathrm{C}_{10}-\mathrm{C}_{21}\right)$ and $12.27 \%$ aromatic $\left(\mathrm{C}_{7}-\mathrm{C}_{10}\right)$. Other compounds observed were $10 \%$ oxygenated and $4.99 \%$ of Ketone.

At pyrolysis temperature of $550^{\circ} \mathrm{C}$, observation made on GC-MS of bio-oil in Fig 3 detected 31 peaks (Table 3). In general, the GC-MS showed that Pyrolysis $550^{\circ} \mathrm{C}$ is composed mostly of $43.85 \%$ Oxygenated, hydrocarbons; approximately $24.91 \%$ aliphatic $\left(\mathrm{C}_{10}-\mathrm{C}_{21}\right)$ and $16.08 \%$ are aromatic $\left(\mathrm{C}_{7}-\mathrm{C}_{10}\right)$. Other compounds observed were 5.78\% Ketones, 3.93\% Nitrogenated, 4.54\% Alkanes and 0.81\% Alkenes (Fig 5).

The Sample GC/MS result at $600^{\circ} \mathrm{C}$ bio-oil of Ficus sawdust was matched with NIST library to identify the compounds (Fig 4). However, 25 peaks were detected and the retention time ranges from 3.77 to 26.49 (Table 4). The identification of the compounds was based on the peak area, molecular weight and molecular formula. At $600^{\circ} \mathrm{C}$, the result was not significantly different from others except for the presence of sulphurous acid. Bio-oil produced at $600{ }^{\circ} \mathrm{C}$ contains mainly of hydrocarbon at highest yield: $74.42 \%$ aliphatic and $5.98 \%$ of aromatic. Others are $11.83 \%$ alkenes and $4.08 \%$ oxygenated (Fig 5).

Out of the peaks detected in the GC-MS of Bio-oil, Oxalic acid and other acids such as phthalic acid, Benzoic acid were at $500^{\circ} \mathrm{C}$, with emergence of 10-12-Pentacosadiynoic acid and 1, 2-Benzenedicarboxylic acid at $550^{\circ} \mathrm{C}$ 
and Sulphurous acid at $600^{\circ} \mathrm{C}$ (Acikalin, 2012) with abundant hydrocarbons which are useful Co-products use in meat browning, food flavour, preservatives, adhesives and other useful chemicals (Czernik and Bridgwater, 2004). Various compounds identified were hydrocarbons (Aliphatic and Aromatic), oxygenated, Ketone (Mahinpey et al., 2009). The presences of aromatic and oxygenated compounds were said to be attributed to its biopolymer textures such as cellulose and hemicellulose (Tsai et al., 2006).

The presence of Oxalic acid in bio-oil is an indication that it can be used in bleaching pulp and also used in baking powder (Wilhelm, 2002); The detected Phtalic acid in bio-oil at $500^{\circ} \mathrm{C}$ and $600^{\circ} \mathrm{C}$ was found to be an important industrial chemical, especially for the large-scale production of plasticizers for plastics and Phthalic anhydride treated with cellulose acetate gives cellulose acetate phthalate (CAP) known to have antiviral activity (Neurath, 2000).

Benzoic acid detected in pyrolysis oil at $500^{\circ} \mathrm{C}$ is a component of an ointment used in the treatment of fungal skin disease such as ringworm, and athlete's foot (Charles et al., 2004).

\section{CONCLUSION}

i. The observation made shows that bio-oil yield was influenced with increase in temperature. The ultimate analysis shows that pyrolysis oil of Ficus biomass is relatively not difficult to burn because the oxygen content is low and that makes the heating value to be high. High oxygen content in pyrolysis oil is not attractive for the production of fuel.

ii. The heating value of bio-oil was observed to be high; however, the low ash content of bio-oil confirmed its high heating value.

iii. Bio-oil yield, bio-oil properties and their composition changed with increase in temperature. And from the result of GC-MS obtained, functional groups were more intense at $500^{\circ} \mathrm{C}$ pyrolysis due to higher degree of cross-linking

iv. Also, GC-MS peaks showed that the bio-oil was mostly composed of hydrocarbons with the presence of Oxalic, Benzoic and Pthalic acid.

v. The low temp with observed high carbon and hydrogen content at $500^{\circ} \mathrm{C}$ temperature suggested high quality fuel properties compared to the bio-oil at $600^{\circ} \mathrm{C}$.

\section{REFERENCES}

Acikalin, K., Karaca, F. and Bolat, E. 2012. Pyrolysis of pistachio shell: Effects of pyrolysis conditions and analysis of products. Fuel, 95, 169-177. http://dx.doi.org/10.1016/j.fuel.2011.09.037.

Bardalai M. and Mahanta D. K 2015. A Review of Physical Properties of Biomass Pyrolysis Oil. International Journal of Renewable Energy Research. Vol.5, No.1, 2015, pp 277-286.

Braz, C. E., Cmkovic P. 2014. Physical characterization of biomass samples for application in pyrolysis process, chemical Engineering Transactions, 37,523-528 DOI:10.3303/CET 1437088.

Bertero, M., Gorostegui, H.A., Orrabalis, C.J., Guzman, C. A., Caladri, E.L and Sedran, U. "Characterisation of the liquid products in the pyrolysis of residual chanar and palm fruit biomasses", Fuel, vol.116, pp. 409-414, 2014.

Biswal, B., Kumar S, and R.K. Singh, K. 2013. "Production of hydrocarbon liquid by thermal pyrolysis of paper cup waste”, Journal of Waste Management, vol.7. ID 731858, 2013.

Bridgwater, A.V., Meier D. and Radlein, D. 1999. An Overview of Fast Pyrolysis of Biomass. Journal of Organic Geochemistry, 30: 1479-1493.

Brown, T. R., Wright, M. M., and Brown, R. C. 2011. Estimating profitability of two biochar production scenarios: Slow pyrolysis vs fast pyrolysis. Biofuels, Bioproducts and Biorefining, 5, 54-68. http://dx.doi.org/10.1002/bbb.254.

Charles, O. W., Ole, G. and John, H. B. 2004. Wilson and Gisvold's Textbook of Organic Medicinal and Pharmaceutical. Lippincott Williams and Wilkins. P. 234. ISBN 0-7817-3481-9.

Czernik, S., and Bridgwater, A. V. 2004. Overview of applications of biomass fast pyrolysis oil. Energy and Fuels, 18, 590-598. http://dx.doi.org/10.1021/ef034067u

Demiral, I., Eryazici, A. and Sensoz, S. 2013. "Bio-oil production from pyrolysis of corn cob (Zea mays L.)", Biomass and Bioenergy, vol. 36, pp. 43-49, 2012.

Fei Y., Shaobo D., Paul C., Yuhuan L., Yiqin W., Andrew O., David K., and Roger R. 2007. Physical and Chemical Properties of Bio-oils from microwave pyrolysed of Corn Stover. Applied Biochemistry and Biotechnology Vol.136-140, 2007.

He, R., Ye, X. P., English, B. C., and Satrio, J. A. (2009): Influence of Pyrolysis Condition on Switchgrass Biooil yield and Physicochemical Properties. Bioresource Technology, 100, 5305-5311. http://dx.doi.org/10.1016/j.biortech.2009.02.069.

Ingram, L. 2008. Pyrolysis of wood and bark in an auger reactor: physical properties and chemical analysis of the produced bio-oils. Energy \& Fuels, Vol. 22(1), pp. 614-225. 
Kazagic A. and Smajevic I., 2007. Experimental investigation of ash behavior and emissions during combustion of Bosnian coal and biomass Energy, 32, 2006 - 2016.

Kiky C. S, Nino R., Sabar P. S. 2015. Bio-oil from Fast Pyrolysis of Empty Fruit Bunch at Various Temperature Conference and Exhibition Indonesia - New, Renewable Energy and Energy Conservation (The 3rd IndoEBTKE ConEx 2014) Energy Procedia 65 ( 2015 ) 162 - 169.

Lafferly F.W. 1980. Registry of mass spectral data, ed. Wiley New York, 1989, 5-9.

Lim C.H., Lam H L. (2013) Biomass Demand-Resources Value Targueting Chemical Engineergin Transactions, $35,631-636$.

Mahinpey, N., Murugan, P., Mani, T., and Raina, R. 2009. Analysis of bio-oil, biogas, and biochar from pressurized pyrolysis of wheat straw using a tubular reactor. Energy and Fuels, 23, 2736-2742. http://dx.doi.org/10.1021/ef8010959.

Mohamad, A. S., Chow, M. C. and Nor Kartini A.B. 2009. Bio-oils from Pyrolysis of Oil Palm Empty Fruit Bunches. American Journal of Applied Sciences 6 (5): 869-875, 2009.

Mullen, C.Z., Boateng, A.A., Goldberg, N. M., Lima, I.M., Laird, D.A and Hicks, K. B 2010. "Bio-oil and biochar production from corn cobs and stover by fast pyrolysis", Biomass and Bioenergy, vol.. 34, pp. 67-74, 2010.

Nanda S., Pravakar, M., Janusz, A. K. and Ajay, K. D. 2014. Physico-Chemical Properties of Bio-Oils from Pyrolysis of Lignocellulosic Biomass with High and Slow Heating Rate. Journal of Energy and Environment Research; Vol. 4, No. 3; 2014.

Neurath, A. R 2000 "Microbicide for prevention of sexually transmitted disease using a pharmaceutical excipient".AIDS Patient Care STDs. 14(4): 215-9. Dio: 10.1089/10879100317830. PMID 10806641.

Oasmaa, A. and Czernik, S. 1999. Fuel oil quality of biomass pyrolysis oils state of the art for the end users. Energy \& Fuels, 13, 914-921.

Oasmaa, A., Leppämäki, E., Koponen, P., Levander, J. and Tapola, E. 1997. Physical characterization of biomassbased pyrolysis liquids, Application of standard fuel oil analyses (VTT Publications 306). Technical Research Centre of Finland.

Oasmaa, A. and Peacock, C.A. 2001. A guide to physical property characterization of biomass derived fast pyrolysis liquids, (VTT Publications 450). Technical Research Centre of Finland.

Oluwadare A. O., Anguruwa G. T and Sotannde O. A. 2016. Characterization of energy value of lignin extracted from mill wood residues of Gmelina arborea and Tectona grandis. Journal of Forest Sciences and Environment. Vol.1(1):14-20.

Thangalazhy-Gopakumar, S., Adhikari, S., Ravindran, H., Gupta, R. B., Fasina, O., Tu, M and Fernando, S. D. 2010. Physiochemical properties of bio-oil produced at various temperatures from pinewood using an auger reactor. Bioresource Technology, Vol. 101, pp. 8389-95 (2010).

Tsai, W.T., Lee, M. K and Chang, Y.M. 2006. Fast pyrolysis of rice straw, sugarcane bagasse and coconut shell in an induction-heating reactor. J. Anal. Appl. Pyrol., 76: 230-237. DOI:10.1016/j.jaap.2005.11.007.

Stein's 1990. National Institute of Standards and Technology (NIST). Mass spectral Database and Software, Version 3.02, USA, 1990, 39-42.

Sukumaran, R. K., Surender, V. J., Sindhu, R., Binod, P., Janu, K. U., Sajna, K. V. and Pandey, A. 2010. Lignocellulosic ethanol in India: Prospects, challenges and feedstock availability. Bioresource Technology, 101, 4826-4833. http://dx.doi.org/10.1016/j.biortech.2009.11.049.

Wilhelm, R. and Minoru, T. 2002. "Oxalic acid" in Ullmann's Encyclopedia of Industrial Chemistry, 2001. WileyVCH, Weinheim. Doi:10.1002/14356007.a18_247. 
TABLES

Table 1. Mean values of Physical Properties, Elemental and Proximate Analysis of Bio-oil at different temperature regime

\begin{tabular}{llllc}
\hline Variables & \multicolumn{3}{c}{ Temperature Regime } & \\
\hline & $\mathbf{5 0 0}^{\circ} \mathbf{C}$ & $\mathbf{5 5 0}^{\circ} \mathbf{C}$ & $\mathbf{6 0 0}^{\circ} \mathbf{C}$ & Mean \\
\cline { 2 - 4 } $\mathrm{pH}$ & 3.77 & 3.42 & 3.09 & 3.43 \\
Density $\left(\mathrm{kg} / \mathrm{dm}^{3}\right)$ & 1.14 & 1.12 & 1.11 & 1.12 \\
Moisture content $(\%)_{\text {Kinematic viscosity }}$ & 24.06 & 25.80 & 27.63 & 25.85 \\
Flash point $^{\circ} \mathrm{C}$ & 513.17 & 299.90 & 86.67 & 299.92 \\
Cloud point $^{\circ} \mathrm{C}$ & 74.33 & 87.66 & 101.00 & 87.67 \\
Pour point ${ }^{\circ} \mathrm{C}$ & 7.00 & 8.33 & 9.67 & 8.33 \\
Coradson Carbon Residue $(\%)$ & 4.00 & 4.50 & 5.00 & 4.50 \\
Carbon & 0.20 & 0.23 & 0.26 & 0.23 \\
Hydrogen & 76.39 & 77.42 & 78.45 & 77.42 \\
Nitrogen & 5.13 & 4.76 & 4.41 & 4.77 \\
Oxygen & 0.13 & 0.11 & 0.08 & 0.10 \\
Volatile Matter $(\%)$ & 18.48 & 17.80 & 17.80 & 17.81 \\
Ash Content $(\%)$ & 23.98 & 26.28 & 26.57 & 26.28 \\
Fixed Carbon $(\%)$ & 0.09 & 0.08 & 0.05 & 0.07 \\
Heating Value $\mathrm{Mj} / \mathrm{Kg}^{1}$ & 73.93 & 73.67 & 73.61 & 73.67 \\
\hline
\end{tabular}

Table 2 Bioactive Compounds detected in pyrolysis oil at $500^{\circ} \mathrm{C}$

\begin{tabular}{llllll}
\hline Peak & $\begin{array}{l}\text { Retention } \\
\text { Time }\end{array}$ & $\begin{array}{l}\text { Peak } \\
\text { Area } \%\end{array}$ & $\begin{array}{l}\text { Molecular } \\
\text { Weight }\end{array}$ & $\begin{array}{l}\text { Molecular } \\
\text { Formular }\end{array}$ & Bioactive Compounds \\
\hline 1 & 3.77 & 5.78 & 92 & $\mathrm{C}_{7} \mathrm{H}_{8}$ & Benzene \\
2 & 3.94 & 4.99 & 112 & $\mathrm{C}_{8} \mathrm{H}_{16}$ & Cyclohexane \\
3 & 4.21 & 13.46 & 128 & $\mathrm{C}_{9} \mathrm{H}_{20}$ & 2,4-dimethylheptane \\
4 & 5.19 & 7.28 & 106 & $\mathrm{C}_{8} \mathrm{H}_{10}$ & 1,2-xylene dimethylbenzene \\
5 & 5.58 & 8.96 & 142 & $\mathrm{C}_{10} \mathrm{H}_{22}$ & 2,7-dimethyloctane \\
6 & 6.85 & 7.95 & 142 & $\mathrm{C}_{10} \mathrm{H}_{22}$ & 2-methylnonane \\
7 & 8.19 & 5.53 & 142 & $\mathrm{C}_{10} \mathrm{H}_{22}$ & 2,7-dimethyloctane \\
8 & 10.09 & 4.31 & 212 & $\mathrm{C}_{15} \mathrm{H}_{32}$ & 4,8-dimethyldecane \\
9 & 12.18 & 3.75 & 184 & $\mathrm{C}_{13} \mathrm{H}_{28}$ & Tridecane \\
10 & 13.91 & 4.53 & 156 & $\mathrm{C}_{11} \mathrm{H}_{24}$ & 2-methyldecane \\
11 & 15.51 & 3.82 & 156 & $\mathrm{C}_{11} \mathrm{H}_{24}$ & 2,3,3-trimethyloctane \\
12 & 16.88 & 7.29 & 193 & $\mathrm{C}_{9} \mathrm{H}_{11} \mathrm{~N}_{3} \mathrm{O}_{2}$ & Benzoic and Phthalic acid \\
13 & 18.13 & 2.94 & 184 & $\mathrm{C}_{13} \mathrm{H}_{28}$ & 3,7-dimethylundecane \\
14 & 18.20 & 2.11 & 268 & $\mathrm{C}_{19} \mathrm{H}_{40}$ & 6-methyloctadecane \\
15 & 19.27 & 2.71 & 341 & $\mathrm{C}_{20} \mathrm{H}_{39} \mathrm{NO}_{3}$ & Oxalic acid \\
16 & 20.36 & 2.66 & 156 & $\mathrm{C}_{11} \mathrm{H}_{24}$ & 2,3,3-trimethyloctane \\
17 & 21.60 & 2.60 & 170 & $\mathrm{C}_{12} \mathrm{H}_{26}$ & 3,4,5,6tetramethyloctane \\
18 & 23.15 & 2.41 & 282 & $\mathrm{C}_{20} \mathrm{H}_{42}$ & 2,6,10,14 tetramethylhexadecan \\
19 & 24.53 & 2.26 & 310 & $\mathrm{C}_{22} \mathrm{H}_{46}$ & 8, heptylpentadecane \\
20 & 25.60 & 2.34 & 282 & $\mathrm{C}_{20} \mathrm{H}_{42}$ & Eicosane \\
21 & 26.49 & 2.32 & 226 & $\mathrm{C}_{16} \mathrm{H}_{34}$ & Hexadecane \\
\hline
\end{tabular}


Table 3 Bioactive compounds detected in Pyrolysis oil at $550^{\circ} \mathrm{C}$

\begin{tabular}{|c|c|c|c|c|c|}
\hline Peak & $\begin{array}{l}\text { Retention } \\
\text { Time }\end{array}$ & $\begin{array}{l}\text { Peak } \\
\text { Area \% }\end{array}$ & $\begin{array}{l}\text { Molecular } \\
\text { Weight }\end{array}$ & $\begin{array}{l}\text { Molecular } \\
\text { Formular }\end{array}$ & Bioactive Compounds \\
\hline 1 & 5.57 & 1.42 & 136 & $\mathrm{C}_{10} \mathrm{H}_{16}$ & 2,6,6-Trimethylbicyclo [3.1.1]hept-2-ene \\
\hline 2 & 6.18 & 0.30 & 136 & $\mathrm{C}_{10} \mathrm{H}_{16}$ & Bicyclo3,1,0 hexane \\
\hline 3 & 6.28 & 2.75 & 136 & $\mathrm{C}_{10} \mathrm{H}_{16}$ & 6,6-dimethyl-2-methylene \\
\hline 4 & 6.37 & 0.44 & 136 & $\mathrm{C}_{10} \mathrm{H}_{16}$ & 7-methyl-3-methylene-1,6 octadiene \\
\hline 5 & 7.09 & 5.72 & 136 & $\mathrm{C}_{10} \mathrm{H}_{16}$ & Cyclohexene \\
\hline 6 & 7.28 & 0.30 & 136 & $\mathrm{C}_{10} \mathrm{H}_{16}$ & 1,3,6-Octatriene \\
\hline 7 & 8.21 & 5.48 & 154 & $\mathrm{C}_{10} \mathrm{H}_{18} \mathrm{O}$ & 1,6-Octadien-3-ol \\
\hline 8 & 10.72 & 0.65 & 152 & $\mathrm{C}_{8} \mathrm{H}_{12} \mathrm{~N}_{2} \mathrm{O}$ & Benzene, 2,4-dimethoxy-1-methyl \\
\hline 9 & 11.77 & 0.37 & 136 & $\mathrm{C}_{10} \mathrm{H}_{16}$ & 1,3,6-Heptatriene, \\
\hline 10 & 11.95 & 0.89 & 204 & $\mathrm{C}_{15} \mathrm{H}_{24}$ & 1H-Cyclopenta[1,3]cyclopropa[1,2]benzene \\
\hline 11 & 12.40 & 3.98 & 204 & $\mathrm{C}_{15} \mathrm{H}_{24}$ & Naphthalene \\
\hline 12 & 12.59 & 7.14 & 204 & $\mathrm{C}_{15} \mathrm{H}_{24}$ & 1,5-Cyclooctadiene \\
\hline 13 & 12.86 & 2.27 & 204 & $\mathrm{C}_{15} \mathrm{H}_{24}$ & 1H-Benzocycloheptene \\
\hline 14 & 13.05 & 7.16 & 204 & $\mathrm{C}_{15} \mathrm{H}_{24}$ & Cyclobutene, \\
\hline 15 & 13.12 & 3.10 & 190 & $\mathrm{C}_{15} \mathrm{H}_{24}$ & 1,5,9,11-Tridecatetraene 12-methyl \\
\hline 16 & 13.29 & 6.11 & 204 & $\mathrm{C}_{15} \mathrm{H}_{24}$ & 1,6,10-Dodecatriene \\
\hline 17 & 13.38 & 2.87 & 204 & $\mathrm{C}_{15} \mathrm{H}_{24}$ & Cyclohexene \\
\hline 18 & 13.55 & 6.05 & 204 & $\mathrm{C}_{15} \mathrm{H}_{24}$ & 1,3,6-Octatriene \\
\hline 19 & 13.93 & 8.08 & 204 & $\mathrm{C}_{15} \mathrm{H}_{24}$ & 1,6-Cyclodecadiene \\
\hline 20 & 14.06 & 4.53 & 206 & $\mathrm{C}_{15} \mathrm{H}_{26}$ & Naphthalene \\
\hline 21 & 14.20 & 7.12 & 204 & $\mathrm{C}_{15} \mathrm{H}_{24}$ & $1,6,10$-Dodecatriene, \\
\hline 22 & 14.45 & 5.12 & 204 & $\mathrm{C}_{15} \mathrm{H}_{24}$ & Cyclohexene, \\
\hline 23 & 14.64 & 2.70 & 204 & $\mathrm{C}_{10} \mathrm{H}_{16}$ & 3,7-dimethyl-1,3,6-Octatriene \\
\hline 24 & 14.98 & 4.31 & 222 & $\mathrm{C}_{15} \mathrm{H}_{26} \mathrm{O}$ & 3,7,11-trimethyl-1,6,10-dodecatrien-3-ol \\
\hline 25 & 15.20 & 1.86 & 204 & $\mathrm{C}_{15} \mathrm{H}_{24}$ & Naphthalene \\
\hline 26 & 15.61 & 1.74 & 206 & $\mathrm{C}_{25} \mathrm{H}_{42} \mathrm{O}_{2}$ & 10, 12-Pentacosadiynoic acid \\
\hline 27 & 15.70 & 2.15 & 220 & $\mathrm{C}_{19} \mathrm{H}_{34}$ & 4,6,9-Nonadecatriene \\
\hline 28 & 15.87 & 1.95 & 222 & $\mathrm{C}_{15} \mathrm{H}_{26} \mathrm{O}$ & $\begin{array}{l}\text { Cyclohexanemethol,4-trimethyl-3-1- } \\
\text { methylethenyl }\end{array}$ \\
\hline 29 & 16.20 & 0.96 & 166 & $\mathrm{C}_{9} \mathrm{H}_{14} \mathrm{O}$ & $\begin{array}{l}\text { 3,5-Dimethylcyclohex-1-ene-4- } \\
\text { carboxaldehyde }\end{array}$ \\
\hline 30 & 17.01 & 1.89 & 152 & $\mathrm{C}_{10} \mathrm{H}_{16} \mathrm{O}$ & 2,4-Cyclohexadiene-1-methanol, \\
\hline 31 & 19.84 & 0.60 & 278 & $\mathrm{C}_{16} \mathrm{H}_{22} \mathrm{O}_{4}$ & 1,2-Benzenedicarboxylic acid \\
\hline
\end{tabular}


Table 4 Bioactive Compounds detected in Pyrolysis oil at $600^{\circ} \mathrm{C}$

\begin{tabular}{llllll}
\hline Peak & $\begin{array}{l}\text { Retention } \\
\text { Time }\end{array}$ & $\begin{array}{l}\text { Peak } \\
\text { Area } \%\end{array}$ & $\begin{array}{l}\text { Molecular } \\
\text { Weight }\end{array}$ & $\begin{array}{l}\text { Molecular } \\
\text { Formular }\end{array}$ & Bioactive Compounds \\
\hline 1 & 3.77 & 1.51 & 92 & $\mathrm{C}_{7} \mathrm{H}_{8}$ & 1, 3, 5-Cycloheptatriene. \\
2 & 3.94 & 1.50 & 92 & $\mathrm{C}_{7} \mathrm{H}_{16}$ & Trans-1,3 dimethylCyclohexane \\
3 & 4.21 & 4.08 & 92 & $\mathrm{C}_{9} \mathrm{H}_{20}$ & 2,3,4-trimethylhexane \\
4 & 5.19 & 2.40 & 92 & $\mathrm{C}_{8} \mathrm{H}_{10}$ & 1,2-dimethylbenzene \\
5 & 5.58 & 3.58 & 92 & $\mathrm{C}_{8} \mathrm{H}_{18}$ & 2,4-dimethylhexane \\
6 & 6.85 & 4.13 & 112 & $\mathrm{C}_{10} \mathrm{H}_{22}$ & 2,7-dimethyloctane \\
7 & 8.19 & 4.12 & 112 & $\mathrm{C}_{10} \mathrm{H}_{22}$ & 2-methylnonane \\
8 & 10.09 & 4.79 & 112 & $\mathrm{C}_{12} \mathrm{H}_{26}$ & 2-methylundecane \\
9 & 11.65 & 1.94 & 112 & $\mathrm{C}_{11} \mathrm{H}_{24}$ & 2,3,7-trimethyloctane \\
10 & 12.18 & 5.61 & 112 & $\mathrm{C}_{13} \mathrm{H}_{28}$ & Tridecane \\
11 & 13.57 & 1.33 & 114 & $\mathrm{C}_{15} \mathrm{H}_{32}$ & 2,6,11-trimethyldodecane \\
12 & 13.96 & 6.65 & 128 & $\mathrm{C}_{13} \mathrm{H}_{28}$ & Tridecane \\
13 & 14.95 & 2.44 & 114 & $\mathrm{C}_{14} \mathrm{H}_{30}$ & 4,6-dimethyl dodecane \\
14 & 15.51 & 6.56 & 128 & $\mathrm{C}_{14} \mathrm{H}_{14}$ & Tetradecane \\
15 & 16.88 & 6.17 & 142 & $\mathrm{C}_{16} \mathrm{H}_{34}$ & Hexadecane \\
16 & 17.50 & 1.75 & 106 & $\mathrm{C}_{18} \mathrm{H}_{38}$ & 2,6,10-trimethylpentadecane \\
17 & 18.12 & 5.27 & 106 & $\mathrm{C}_{14} \mathrm{H}_{30}$ & Tetradecane \\
18 & 18.19 & 4.08 & 106 & $\mathrm{C}_{13} \mathrm{H}_{28}$ & (Sulfurous acid) \\
19 & 19.27 & 4.92 & 106 & $\mathrm{C}_{13} \mathrm{H}_{28}$ & 2-methyldodecane \\
20 & 20.36 & 4.83 & 106 & $\mathrm{C}_{13} \mathrm{H}_{28}$ & Tridecane \\
21 & 21.59 & 4.63 & 128 & $\mathrm{C}_{21} \mathrm{H}_{44}$ & 2-methyleicosane \\
22 & 23.14 & 4.72 & 114 & $\mathrm{C}_{20} \mathrm{H}_{42}$ & 2-methylnonadecane \\
23 & 24.53 & 4.45 & 142 & $\mathrm{C}_{24} \mathrm{H}_{50}$ & Tetracosane \\
24 & 25.60 & 4.36 & 128 & $\mathrm{C}_{14} \mathrm{H}_{30}$ & 2-methyltridecane \\
25 & 26.49 & 4.20 & 128 & $\mathrm{C}_{18} \mathrm{H}_{38}$ & 2-methyleicosane \\
\hline
\end{tabular}

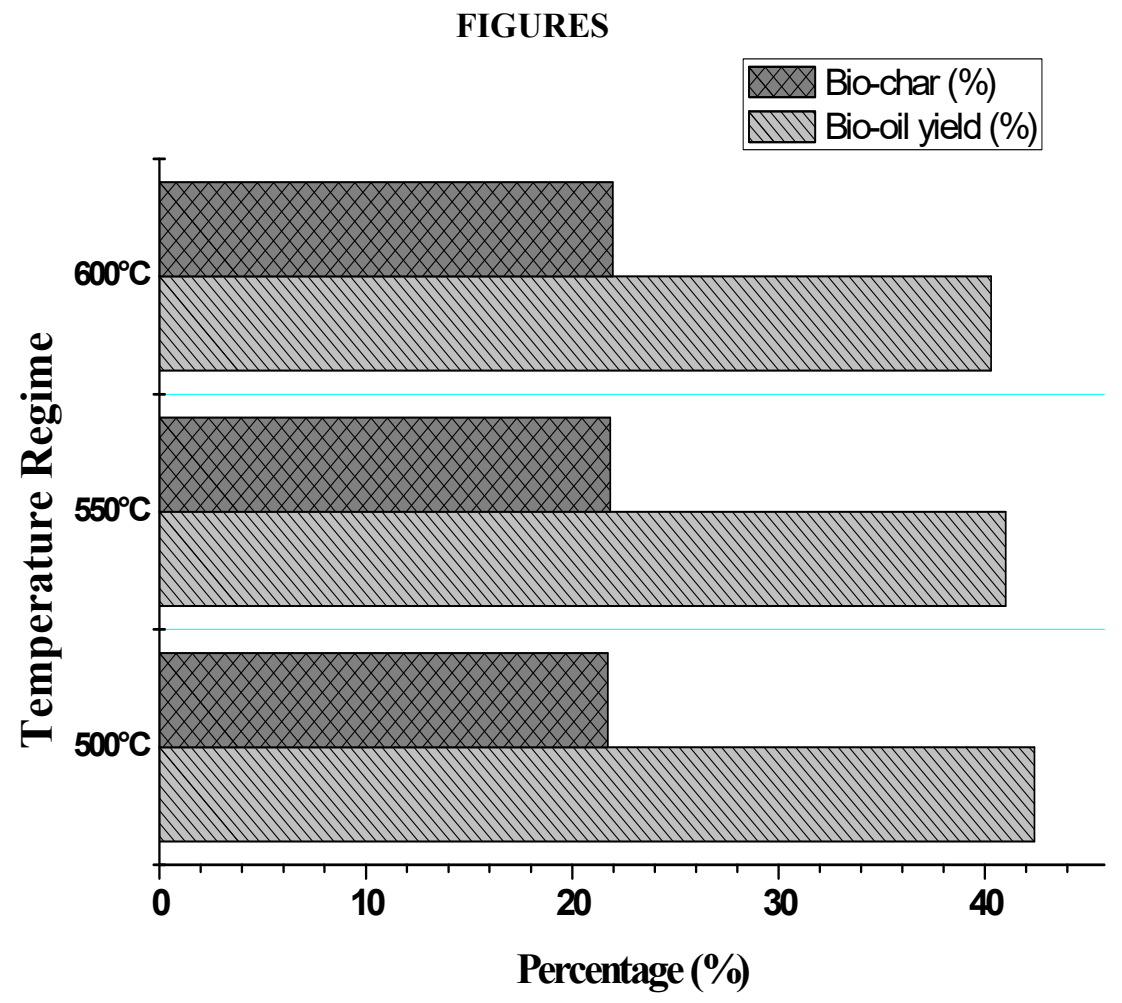

Figure 1. Percentage bio-oil yield and bio-char content 


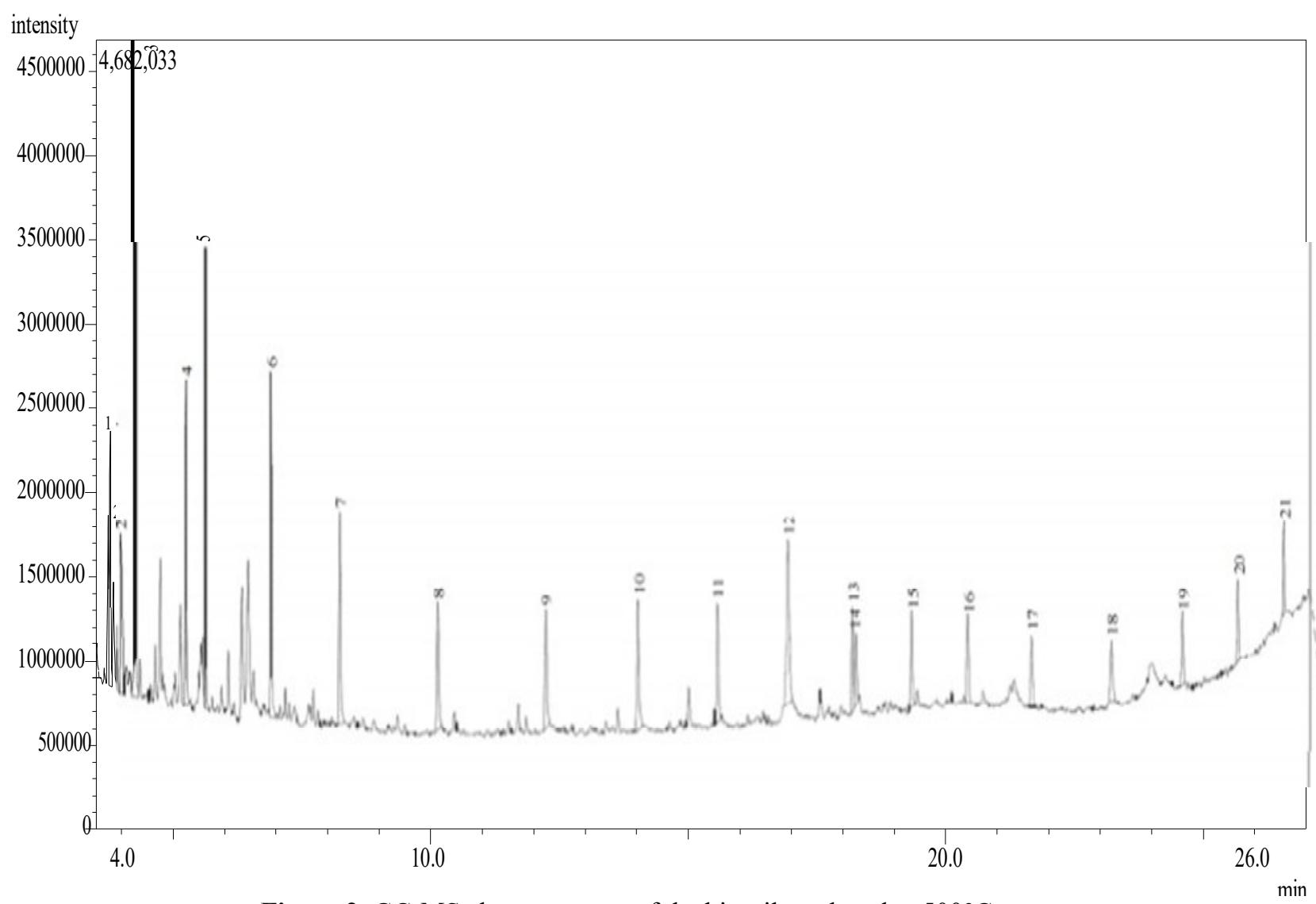

Figure 2. GC-MS chromatogram of the bio-oil produced at $500^{\circ} \mathrm{C}$

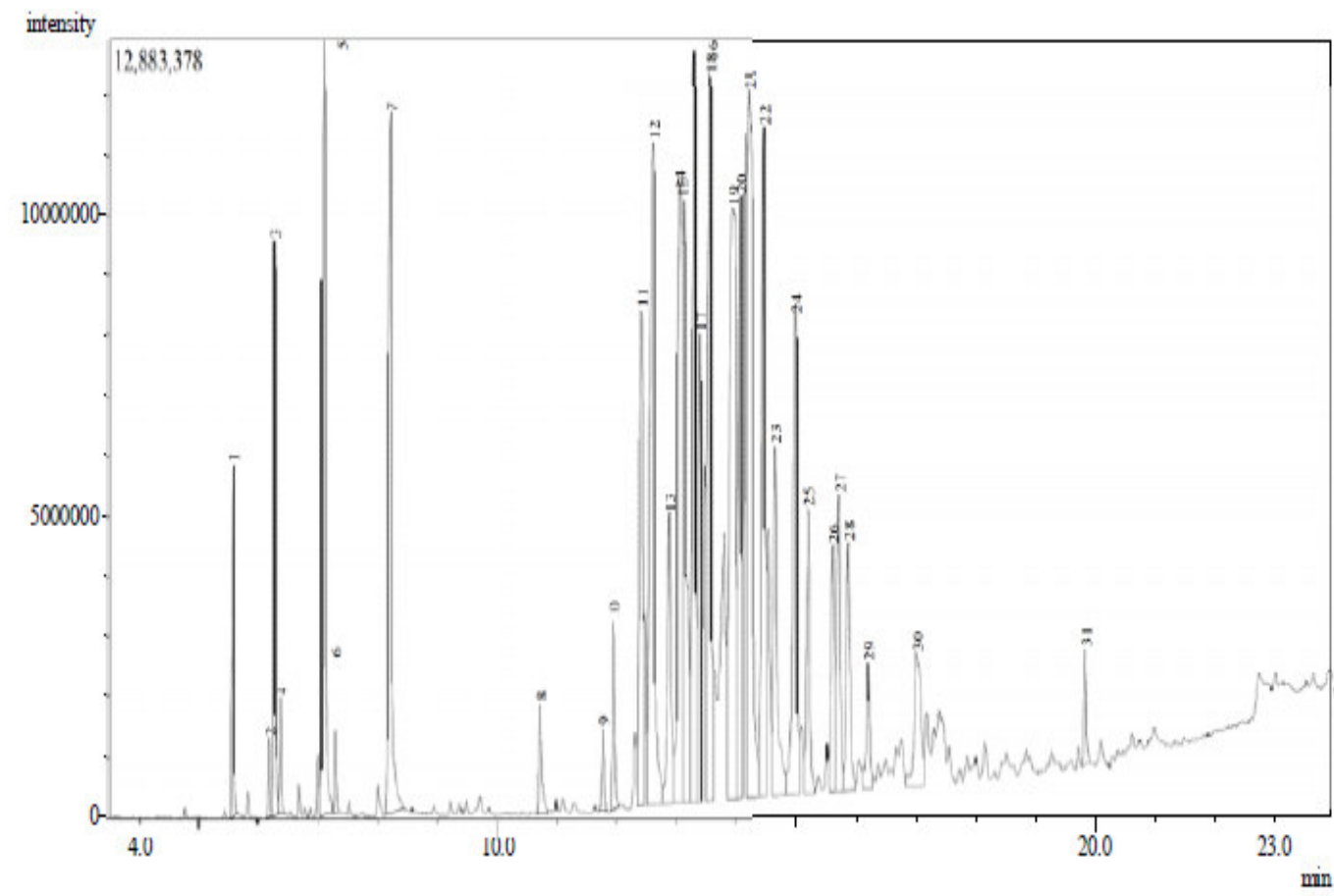

Method

Figure 3. GC-MS of bio-oil produced at $550^{\circ} \mathrm{C}$ 


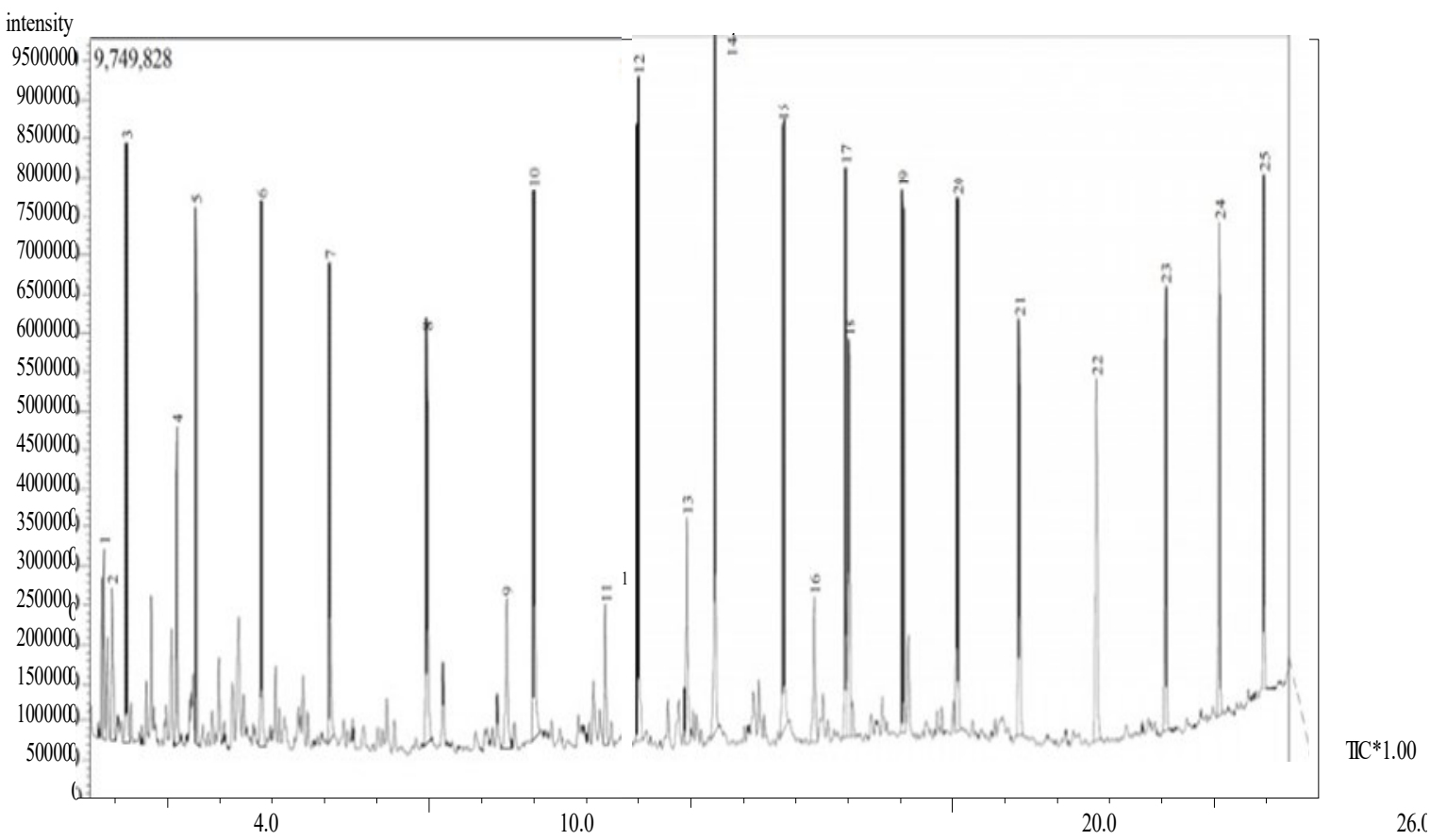

Figure 4. GC-MS of bio-oil produced at $600^{\circ} \mathrm{C}$

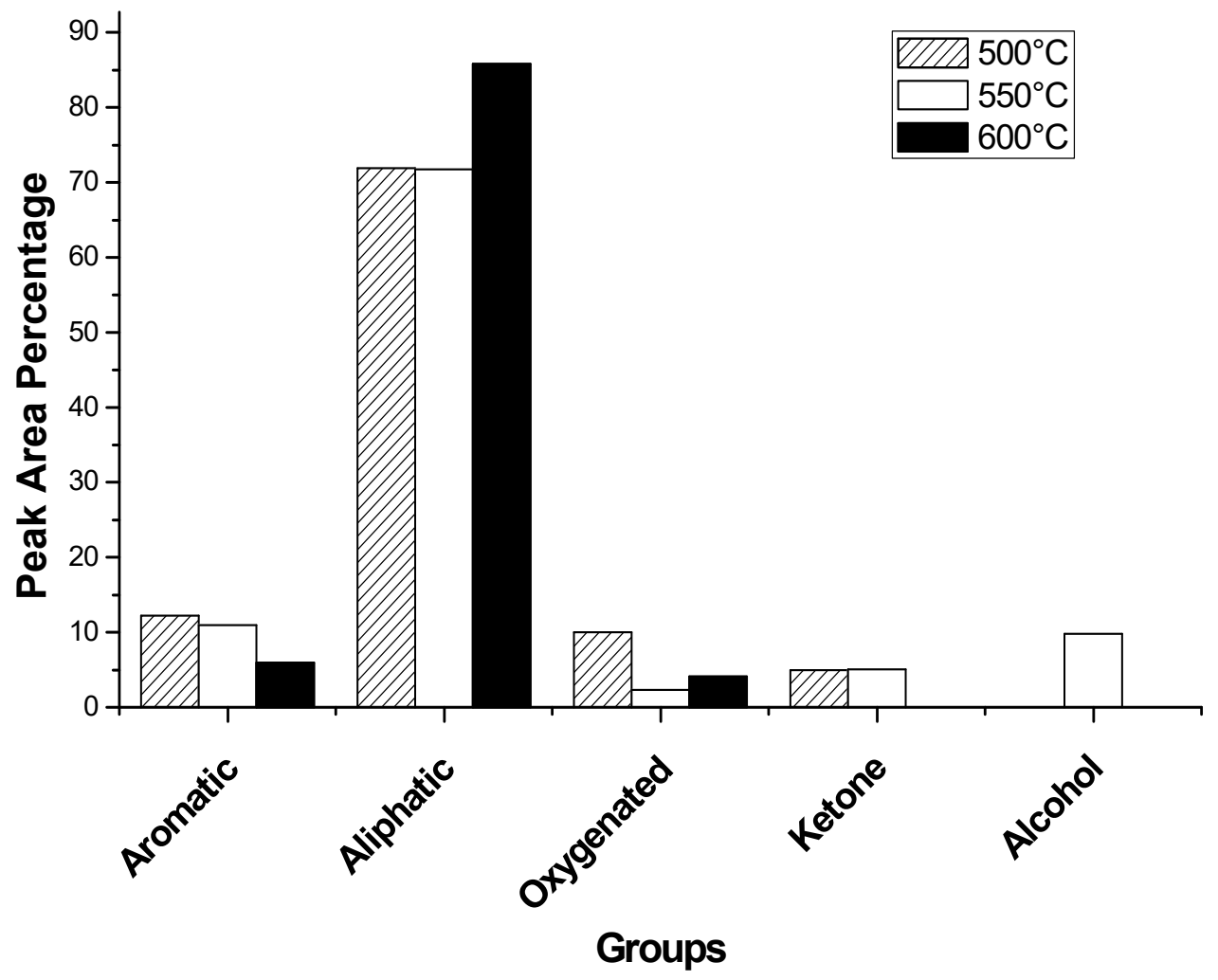

Figure 5. Compounds identified in bio-oil based on peak area percentage 